\title{
Chapter 5
}

\section{Effect of $\mathrm{TiO}_{2}$ Nanotube Calcination Temperature and Oxygen Pressure to Photocatalytic Oxidation of Phenol}

\author{
Farid F. Orudzhev ${ }^{1}$, Abdulgalim B. Isaev ${ }^{1 *}$, Nabi N. Shabanov ${ }^{1,2}$ \\ ${ }^{1}$ Department of Environmental Chemistry and Technology, Dagestan State University, M. \\ Gadjieva, 43a, 367001, Makhachkala, Russian Federation \\ ${ }^{2}$ Analytical Center of Common Access DSC RAS, 94 M. Yaragsky St., Makhachkala 367003, \\ Russia
}

Email: abdul-77@yandex.ru

\begin{abstract}
The influences of oxygen pressure and $\mathrm{TiO}_{2}$ nanotubes calcination temperature on the photocatalytic degradation phenol were investigated. According to experimental results the dissolved oxygen at different pressure and $\mathrm{TiO}_{2}$ calcination temperature was a determining parameter for the photocatalytic degradation of phenol. The calcination temperature of $\mathrm{TiO}_{2}$ nanotubes affects the anatase phase, crystallite size, surface area and pore volume of $\mathrm{TiO}_{2}$ powder and respectively to rate of photodegradation of phenol. The kinetics of photocatalytic degradation of phenol in presence of $\mathrm{TiO}_{2}$ nanotubes at high pressure of oxygen is investigated. The initial rate of photodegradation phenol were increased from 0.21 to $0.52 \mathrm{mg} \cdot 1^{-1} \cdot \mathrm{min}^{-1}$ when the initial oxygen pressure was increased from 0.1 to $0.6 \mathrm{MPa}$ and have linear relationship between phenol oxidation rate and the oxygen pressure. The dissolved oxygen acted as an electron scavenger with formation reactive oxygen species such as the superoxide ion and the hydroxyl radical.
\end{abstract}

\section{Keywords}

Calcinations Temperature, Oxygen Pressure, Phenol, Photocatalytic Degradation, $\mathrm{TiO}_{2}$ Nanotubes

\section{Contents}

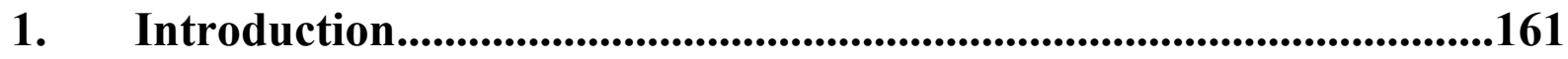

2. Experimental .................................................................................................162 


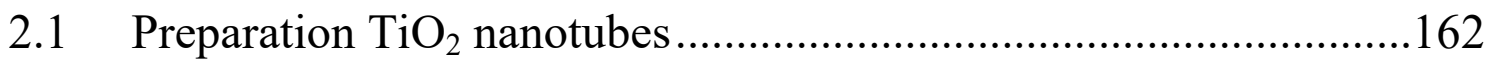

2.2 Characterization $\mathrm{TiO}_{2}$ nanotubes..............................................162

2.3 Photocatalytic activity ...............................................................163

3. Results and discussion ...............................................................................164

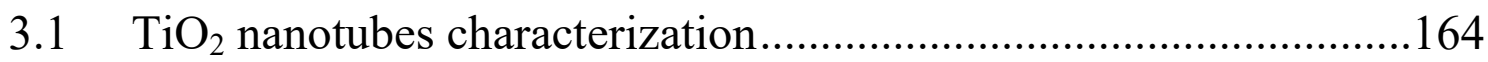

3.2 Effect of calcinations temperature to photocatalytic activity ..........167

3.3 Effect of oxygen pressure to photocatalytic activity ......................168

4. Conclusions..........................................................................................170

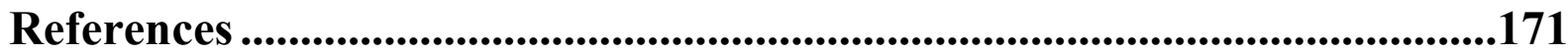

\section{Introduction}

Phenol and phenolic compounds are major pollutants of industrial waste water. Phenol can enter the environment due to its widespread use in various industries such as paper mills, textile and petrochemical industries, paints, pesticide plants, etc. and is a toxic and slowly degradable pollutant $[1,2]$. The traditional methods for phenol and phenolic compounds degradation such as flocculation [3], electrocoagulation [4], adsorption [5], osmosis and chemical oxidation has gained wide application [6]. These physicalchemical technologies have some limitations for application due the transportation of reagents and high cost. The biological treatment is not valid on account of biorefractory characteristics of pollutants [7]. Recently, the heterogeneous photocatalytic oxidation processes have attracted considerable research interests for their high efficiency, environmentally friendly property and cost effectiveness [8-12].

Heterogeneous photocatalysis is widely used for removal of organics and shows a high potential for purification of air, water and on solid surfaces [13]. Over the past few years, there has been an enormous amount of work that has been done regarding applications of heterogeneous photocatalysis for the removal of pollutants [8-10,12,14-20]. The heterogeneous photocatalysis is based on a semiconductor used as catalyst which is activated by UV light. The titania $\left(\mathrm{TiO}_{2}\right)$ is mainly used as the catalyst, because of its high activity at UV light irradiation, nontoxity, photostability and low cost $[19,20]$. Nanocrystalline $\mathrm{TiO}_{2}$ has been widely employed in photocatalytic or photoelectrochemical systems because of its semiconductor characteristics capable of generating charge carriers $[21,22] . \mathrm{TiO}_{2}$ nanotubes are an intensively studied nanosized materials [23-25]. 
The photocatalytic oxidation begins when catalyst absorbs the photon energy equal or higher than its band gap energy and electron can inject from valence band to conduction band with photogeneration holes [8, 26, 27]. Most of the electrons and holes are recombining within nanoseconds and the energy is dissipated as heat. Only a few photogenerated electrons and holes have been migrate to the catalyst surface, where they initiate the redox reaction. In an aqueous $\mathrm{TiO}_{2}$ suspension the valence band holes can react with water to generate hydroxyl radicals which are strong oxidizing agents. Furthermore, the photogenerated electrons react with adsorbed molecular oxygen and reducing it to superoxide radical anion which, in turn, reacts with protons to form peroxide radicals [28].

In this study, we prepared the $\mathrm{TiO}_{2}$ nanotubes by using a low-temperature hydrothermal method without templates and investigated the effect of annealing temperature, dissolved oxygen to photocatalytic activity of prepared nanotubes.

\section{Experimental}

\subsection{Preparation $\mathrm{TiO}_{2}$ nanotubes}

All the reagents used in the experiments were of analytical grade, procured from Ecros Analit, (St-Peterburg, Russia) and used without further purification. In a typical synthesis, $50 \mathrm{~g} \mathrm{P} 25 \mathrm{TiO}_{2}$ was added into the $80 \mathrm{ml} 10 \mathrm{M} \mathrm{NaOH}$ and the mixture were kept in an autoclave at $1300{ }^{\circ} \mathrm{C}$ for $24 \mathrm{~h}$ without stirring. After hydrothermal reaction the products were washed with hot distilled water until neutral $\mathrm{pH}$. TiO2 nanotubes are obtained after the precipitates are washed with a dilute $\mathrm{HCl}$ aqueous solution and distilled water.

\subsection{Characterization $\mathrm{TiO}_{2}$ nanotubes}

Characteristic obtained $\mathrm{TiO}_{2}$ nanotubes samples were performed using electron microscopy, X-ray analysis. The morphology of the $\mathrm{TiO}_{2}$ was characterized by scanning electron microscopy microscope LEO 1450 with analyzer ISYS and EDX system (Leica Micro-systems Wetzlar GmbH, Germany). X-ray diffraction (XRD) studies of synthesized catalysts were carried out at $25^{\circ} \mathrm{C}$ using diffractometer Empyrean series 2 firms PANalytical with $\mathrm{Cu} \mathrm{K \alpha} \alpha_{1}$ radiation $(\mathrm{k}=0,15406 \mathrm{~nm})$. The operating voltage and current were $40 \mathrm{kV}$ and $30 \mathrm{~mA}$, respectively. The diffraction patterns were measured in the $2 \theta$ range of $5-90^{\circ}$ with step size and step time of 0.026 and $197 \mathrm{~s}$ was used for data collection. The data processing was performed using the HighScore Plus software and diffraction database PDF-2. Using Debye-Scherer's equation, the crystallite size was 
calculated [29]. The BET surface area of $\mathrm{TiO}_{2}$ catalyst was measured according to the $\mathrm{N}_{2}$ adsorption isotherm at $77 \mathrm{~K}$ using a Sorbi-MS, ZAO "Meta" sorption analyzer.

\subsection{Photocatalytic activity}

The photocatalytic activities of prepared $\mathrm{TiO}_{2}$ nanotubes were determined by studying the degradation of an aqueous solution of phenol in a teflon cylindrical vessel photocatalytic reactor with volume $200 \mathrm{ml}$ described in more detail in our previous work $[30,31]$. The oxygen pressure created by feeding from a high pressure cylinder to the cell. The cell was depressurized before sampling; then, oxygen was pumped into the cell once again to a specified pressure and the subsequent treatment was performed $(2-3 \mathrm{~h})$. The suspension was intensely stirred with a magnetic stirrer in the course of photocatalysis to prevent the sedimentation of titanium dioxide. For the convenience of stirring, the cell was turned and irradiation was performed from the top (Fig. 1). Teflon vessel 6 with a volume of $200 \mathrm{ml}$ served as a cell, a side of which was made of quartz glass $10 \mathrm{~mm}$ thick (1). The quartz glass was fixed with bronze rings 2 and screws 7 . The solution was poured through orifices 3 , which were than stoppered. Oxygen was pumped through valve 4 , and the pressure was measured with manometer 5 .

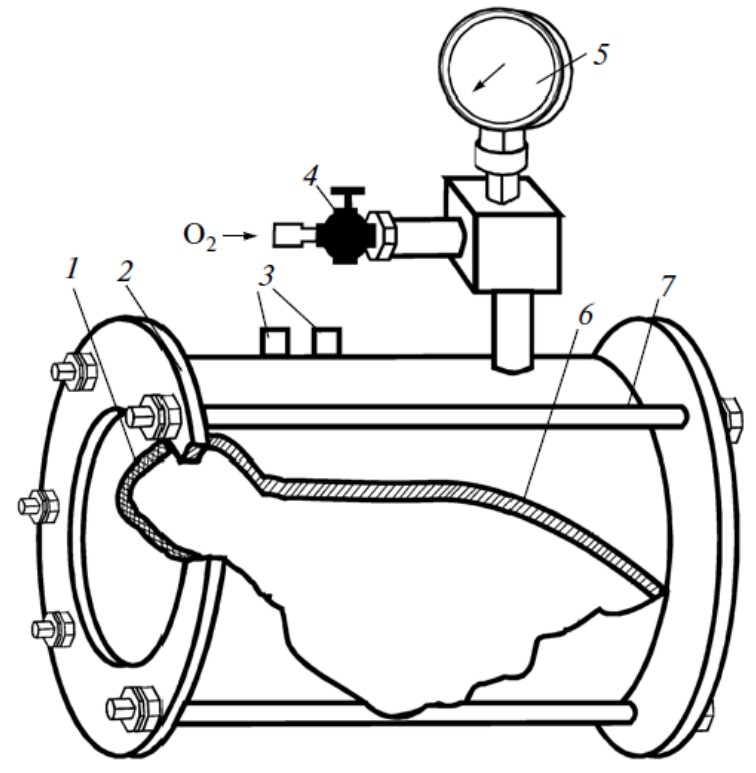

Figure 1. Schematic representation of the cell for photocatalytic oxidation of phenol: (1) quartz window $10 \mathrm{~mm}$ thick, (2) bronze rings, (3) nipples for sampling and loading a suspension of titanium dioxide and a phenol solution, (4) oxygen supply valve, (5) manometer, (6) teflon case $20 \mathrm{~mm}$ thick, and (7) screw. 
The phenol concentration was $10 \mathrm{mg} \cdot \mathrm{l}^{-1}$ and the amount of catalyst added into reactor was $0.1 \mathrm{~g} \cdot \mathrm{l}^{-1}$. The liquid samples were withdrawn at preset time intervals and measured the phenol concentration by fluorimetric method in spectrofluorimeter Model "Fluorat 02 Panorama" (Russia). All the experiments were performed under irradiation 400-W highpressure mercury UV-lamp. The UV-lamp as light source vertically irradiates the reaction mixture.

\section{Results and discussion}

\section{1 $\quad \mathrm{TiO}_{2}$ nanotubes characterization}

Structure and morphology of $\mathrm{TiO}_{2}$ nanotubes was investigated using scanning electron microscopy. As shown in Fig. 2, the powder of $\mathrm{TiO}_{2}$ are of tube morphology with length about $1.0-2.0 \mu \mathrm{m}$ and represent nanotubes agglomeration. The sample has a porous structure which can provide a larger specific surface area. It can be seen that as-formed nanotubes with inner and outer diameters of about 20 and $30 \mathrm{~nm}$ respectively are open at the top end and at the bottom end, just as shown in Fig. 2(b).
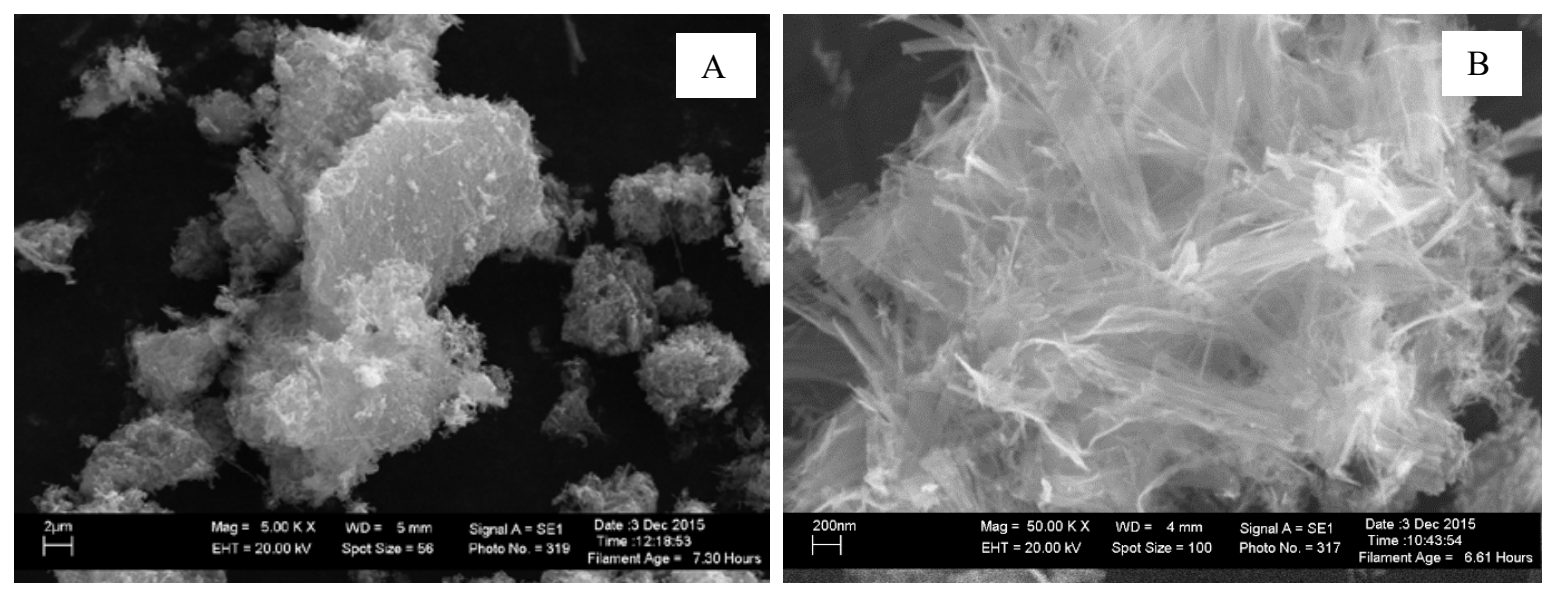

Figure 2. Typical SEM image of samples $\mathrm{TiO}_{2}$ nanotubes.

Fig. 3 shows typical XRD patterns of the $\mathrm{TiO}_{2}$ nanotubes samples prepared at calcinations at different temperature. XRD measurements show that the as-prepared and calcining at $100-200^{\circ} \mathrm{C} \mathrm{TiO}_{2}$ nanotubes powder are amorphous. Annealing at $300^{\circ} \mathrm{C}$ during 1 hour was carried out to crystallize the $\mathrm{TiO}_{2}$ nanotubes to anatase. The XRD results confirm successful conversion, and the evaluation of the main anatase (101) peak of $25^{\circ}$. From the X-ray results, the average crystallite size $\mathrm{TiO}_{2}$ nanotubes was quantitatively calculated. These calculated results are presented in Fig. 4, where lists the 
weight percents of anatase (A) phases in these $\mathrm{TiO}_{2}$ nanotubes, which were determined according to the integrated intensities of anatase (101) peaks in the XRD patterns.

The nanotubes, which calcinations beginning at $300^{\circ} \mathrm{C}$, contain only anatase crystalline structure and at $800^{\circ} \mathrm{C}$ the amorphous phase has been completely transformed into an anatase structure. An increase in calcination time decreases the weight percent of anatase $\mathrm{TiO}_{2}$. This indicates that the formation of the anatase phase of $\mathrm{TiO}_{2}$ is affected by not only calcination temperature but also calcination time [32]. The average size of the anatase crystallites in the $\mathrm{TiO}_{2}$ nanotubes was estimated using the Scherrer equation and the XRD anatase (101) peaks. The calculated crystallite size was increasing when increasing the calcinations temperature. The crystallite size for samples calcined at $300^{\circ} \mathrm{C}$ was $13 \mathrm{~nm}$ and increases to $93 \mathrm{~nm}$ for samples calcined at $800^{\circ} \mathrm{C}$ (Fig. 3), but the surface area decreases when the calcined temperature increases (Table 1). This phenomena have indicated that the brookite and anatase $\mathrm{TiO}_{2}$ are metastable, and will transform exothermally and irreversibly to the rutile $\mathrm{TiO}_{2}$ over a range of temperature at room temperature to $750^{\circ} \mathrm{C}[32]$.

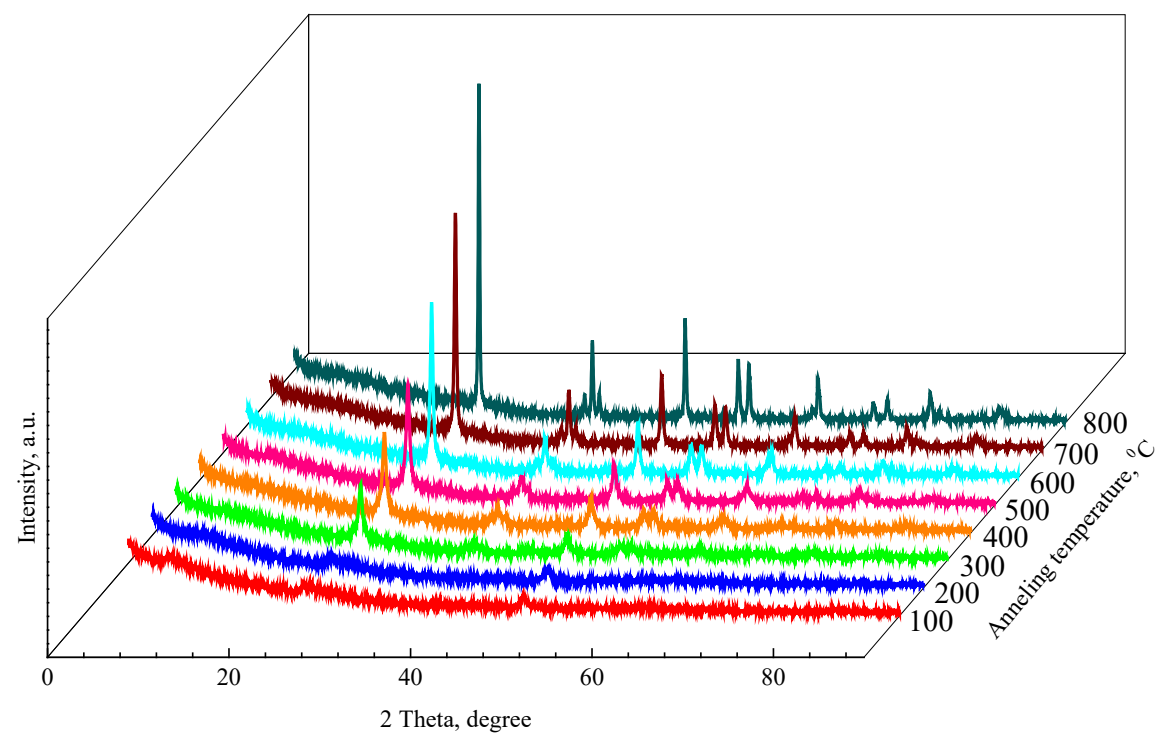

Figure 3. XRD patterns of $\mathrm{TiO}_{2}$ nanotubes prepared by hydrothermal method at different calcination temperatures. 


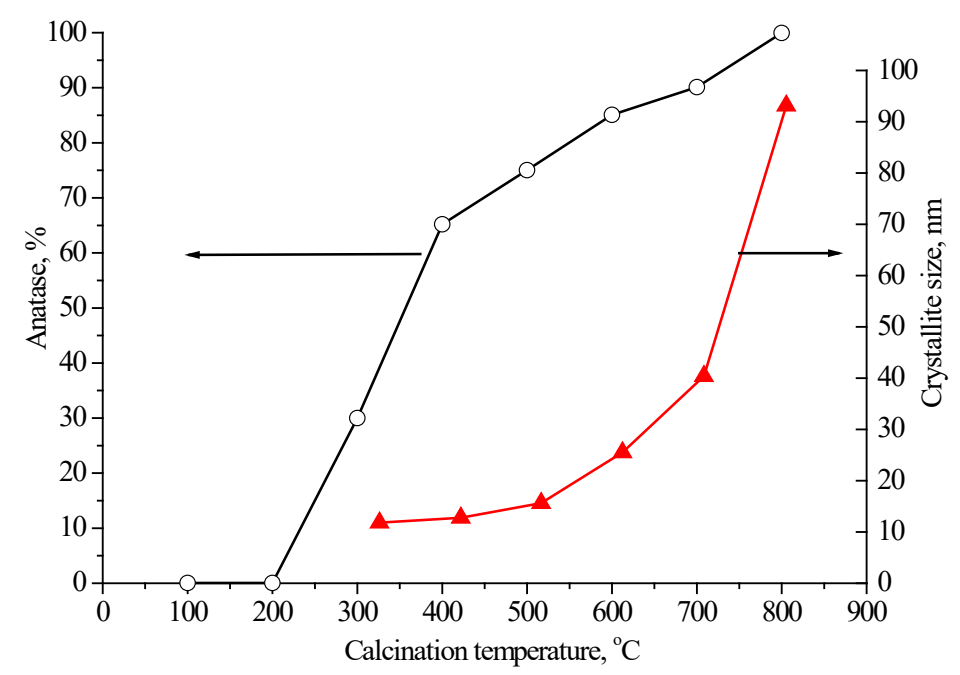

Figure 4. Effect of calcination temperature to percents of anatase phase and crystallite size.

The measure of the specific area of the nanotubes was obtained using the BET method with the nitrogen adsorption-desorption process. Fig. 5 shows an isotherm of $\mathrm{TiO}_{2}$ nanotubes previously heat treated at $100^{\circ} \mathrm{C}$ with a surface area of $265 \mathrm{~m}^{2} \mathrm{~g}^{-1}$. According to the IUPAC classification, the hysteresis loops in Fig. 5 correspond to Type H2, which represents poorly defined pore size and shape distributions [33, 34]. The pore size distribution measurement indicated that the $\mathrm{TiO}_{2}$ nanotubes had a pronounced mesoporosity. As can be seen, from Table 1 the surface area and pore volume in $\mathrm{TiO}_{2}$ nanotubes powder are decreases when increase the calcinations temperature.

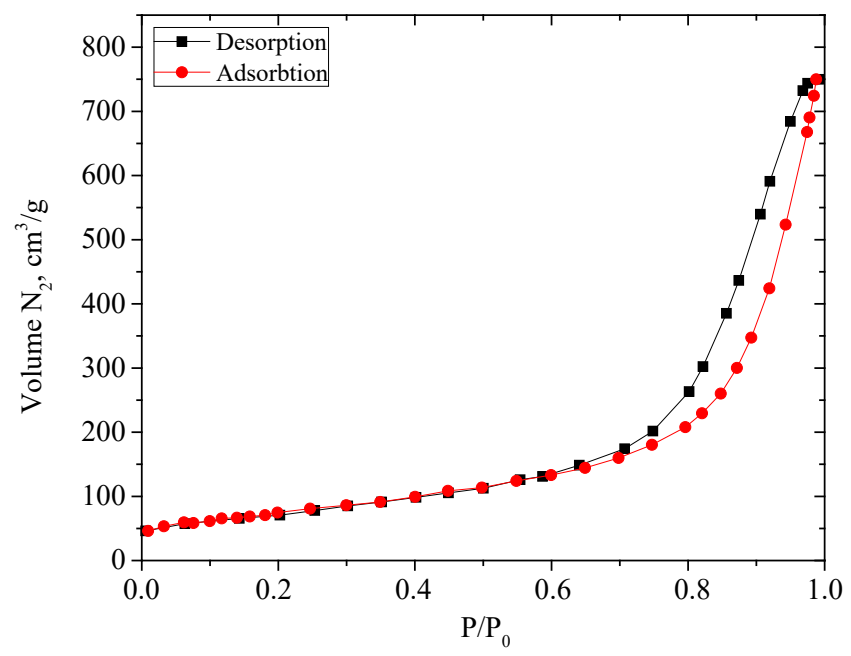

Figure 5. $\quad \mathrm{N}_{2}$ adsorption-desorption isotherms of the $\mathrm{TiO}_{2}$ nanotubes calcined at $1000^{\circ} \mathrm{C}$ 
Table 1. Effect of calcined temperature to $\mathrm{TiO}_{2}$ nanotube powder surface area and pore volume

\begin{tabular}{|l|l|l|}
\hline Calcined temperature, $\left[{ }^{\circ} \mathrm{C}\right]$ & Surface area, $\left[\mathrm{m}^{2} \cdot \mathrm{g}^{-1}\right]$ & Pore volume, $\left[\mathrm{cm}^{3} \cdot \mathrm{g}^{-1}\right]$ \\
\hline 100 & 265 & 0.89 \\
\hline 200 & 230 & 0.71 \\
\hline 300 & 185 & 0.41 \\
\hline 400 & 133 & 0.34 \\
\hline 500 & 90 & 0.28 \\
\hline 600 & 82 & 0.25 \\
\hline 700 & 74 & 0.22 \\
\hline 800 & 56 & 0.18 \\
\hline
\end{tabular}

The high specific surface area and pore volume for samples $\mathrm{TiO}_{2}$ nanotubes calcined at $100^{\circ} \mathrm{C}$ may be associated with the formation of larger mesoporous structure for amorphous phase.

\subsection{Effect of calcinations temperature to photocatalytic activity}

The phenol photocatalytic degradation under UV light irradiation using the prapared $\mathrm{TiO}_{2}$ nanotubes sample as catalyst is shown in Fig. 6. The phenol photodegradation followed by the fluorimetric method.

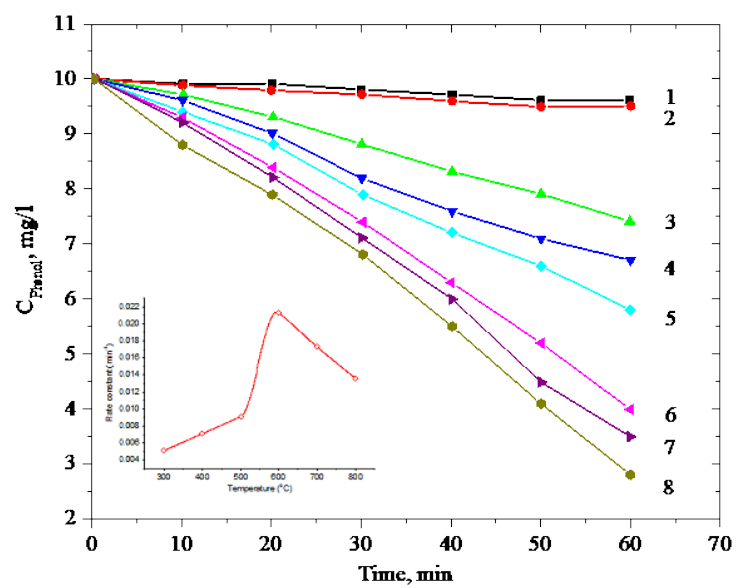

Figure 6. Effect of calcinations temperature of $\mathrm{TiO}_{2}$ nanotubes to photocatalytic oxidation of phenol $\left({ }^{\circ} \mathrm{C}\right): 1-100^{\circ} \mathrm{C}, 2-200^{\circ} \mathrm{C}, 3-300^{\circ} \mathrm{C}, 4-400^{\circ} \mathrm{C}, 5-500^{\circ} \mathrm{C}, 6-$ $800^{\circ} \mathrm{C}, 7-700^{\circ} \mathrm{C}, 8-600^{\circ} \mathrm{C}$. (Insert: temperature dependence of constant rate) ([Ph $]_{0}$ $\left.-10 \mathrm{mg} \cdot \mathrm{l}^{-1},\left[\mathrm{TiO}_{2}\right]_{0}-0.1 \mathrm{~g} \cdot \mathrm{l}^{-1}\right)$. 
The photodegradation of phenol at presence $\mathrm{TiO}_{2}$ nanotube calcined at $100{ }^{\circ} \mathrm{C}$ evidences only $6 \%$ degradation due to UV light alone. What is more, photoactivity of $\mathrm{TiO}_{2}$ is increased due to the calcination temperature increase. Table 2 shows the effect of $\mathrm{TiO}_{2}$ calcination on the phenol degradation rate, after $60 \mathrm{~min}$ of reaction. The constant rate and phenol photodegradation rate were calculated from kinetic curves presented in insert Fig. 6. As observed, the $\mathrm{TiO}_{2}$ photoactivity is increased by increasing calcination temperature up to $600{ }^{\circ} \mathrm{C}$, after which, there is a decrease in the photodegradation of phenol. Higher crystallinity of $\mathrm{TiO}_{2}$ result in the promotion of recombination centers for the photogenerated charges [35]. Thus, $\mathrm{TiO}_{2}$ calcination temperature is a determinant parameter in the design of $\mathrm{TiO}_{2}$ nanotube photocatalysts. The increase in photoactivity due to increase of the crystallite size and existence of only anatase phase which is highly photoactivity.

Table 2. The constants rate and initial rates of photocatalytic oxidation of phenol under UV light irradiation.

\begin{tabular}{|c|c|c|c|c|}
\hline $\begin{array}{c}\text { Calcined } \\
\text { temperature, }\left[{ }^{\circ} \mathrm{C}\right]\end{array}$ & $\begin{array}{c}\text { Constant rate } \\
{\left[\mathrm{min}^{-1}\right]}\end{array}$ & $\begin{array}{c}\text { Initial rate, } \\
\left.[\mathrm{mg} \cdot]^{-1} \cdot \mathrm{min}^{-1}\right]\end{array}$ & $\begin{array}{c}\text { Degree, } \\
{[\%]}\end{array}$ & $\begin{array}{c}\text { Linear } \\
\text { correlation, } \mathrm{R}^{2}\end{array}$ \\
\hline 600 & $0.0213 \pm 0.0006$ & $0.213 \pm 0.006$ & $72.4 \pm 1.1$ & 0.99 \\
\hline 700 & $0.0173 \pm 0.0005$ & $0.173 \pm 0.005$ & $65.5 \pm 0.9$ & 0.99 \\
\hline 800 & $0.0136 \pm 0.0003$ & $0.136 \pm 0.003$ & $60.6 \pm 0.9$ & 0.99 \\
\hline 500 & $0.0091 \pm 0.0004$ & $0.091 \pm 0.004$ & $42.8 \pm 0.8$ & 0.98 \\
\hline 400 & $0.0071 \pm 0.0003$ & $0.071 \pm 0.003$ & $33.7 \pm 0.9$ & 0.99 \\
\hline 300 & $0.0051 \pm 0.0002$ & $0.051 \pm 0.002$ & $26.6 \pm 0.9$ & 0.99 \\
\hline
\end{tabular}

\subsection{Effect of oxygen pressure to photocatalytic activity}

The availability of oxidating agent, as oxygen, in the water phenol solution play an important role in heterogeneous photocatalysis and is one of the determinant factors of the rate of photodegradation of phenol. The dependency of the photocatalytic degradation of phenol on the initial oxygen pressure was studied in the range from 0.1 to $0.6 \mathrm{MPa}$. Typical time-dependent phenol concentration during photocatalytic degradation is illustrated in Fig. 7. As can be seen, when phenol solution with $\mathrm{TiO} 2$ nanotube calcined at $600{ }^{\circ} \mathrm{C}$ was exposed to UV light at oxygen pressure 0.6 MPa, the phenol concentration decreased drastically with illumination time in comparison with the same experiment 
performed in the oxygen pressure of $0.1 \mathrm{MPa}$. The difference between direct photolysis and photocatalysis at oxygen pressure revealed that UV light and $\mathrm{TiO} 2$ photocatalyst together had a significant effect on the degradation of phenol. Since OH radicals was the key feature of $\mathrm{TiO}_{2}$ nanotube assisted photocatalytic process, the degradation of phenol was primarily related to the generated $\mathrm{OH}$ radicals [36]. As can be seen from Fig. 7, the oxygen pressure was contributed to the photocatalytic degradation. The depletion of the phenol concentration during UV light irradiation in presence of $\mathrm{TiO}_{2}$ nanotubes, as recorded in Fig. 7, confirmed that oxygen was involved in the photocatalytic degradation.

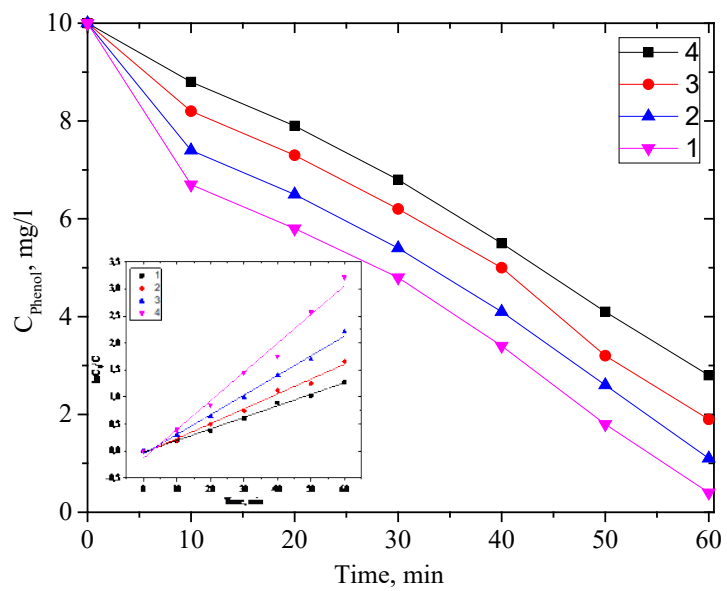

Figure 7. Effect of oxygen pressure to photocatalytic oxidation of phenol $\left({ }^{\circ} C\right): 1-0.1$ $\mathrm{MPa}, 2-0.2 \mathrm{MPa}, 3-0.4 \mathrm{MPa}, 4-0.6 \mathrm{MPa}$. (Insert: kinetic curves) ([Ph] $-10 \mathrm{mg} \cdot \mathrm{l}^{-1}$, $\left.\left[\mathrm{TiO}_{2}\right]_{0}-0.1 \mathrm{~g} \cdot \mathrm{l}^{-1}\right)$.

Accordingly, the improvement of the degradation of phenol, which relate to the increasing initial oxygen pressure, can be attributed to the fact that oxygen acted as electron acceptor to trap the photo induced electron [37]

$\mathrm{O}_{2}+\mathrm{e} \rightarrow \mathrm{O}_{2}{ }^{-}$

$\mathrm{O}_{2}{ }^{-}+\mathrm{H}^{+} \rightarrow \mathrm{HO}_{2}$

$\mathrm{HO}_{2}+\mathrm{HO}_{2} \rightarrow \mathrm{H}_{2} \mathrm{O}_{2}+\mathrm{O}_{2}$

$\mathrm{O}_{2}{ }^{-}+\mathrm{HO}_{2}{ }^{\cdot}+\mathrm{H}^{+} \rightarrow \mathrm{H}_{2} \mathrm{O}_{2}+\mathrm{O}_{2}$

Through the reduction of oxygen, reactive superoxide radical anions (O2.-) was produced (Eq. 1). Fig. 8 shows the relation of the initial rate of phenol photocatalytic oxidation by oxygen pressure. From Fig. 8 one can see, that the increase of oxygen pressure intensifies the phenol oxidation process. In this pressure range there is a linear relationship between 
phenol oxidation rate and the oxygen pressure. This relationship is described by a linear equation (Eq. 5) with a linear correlation coefficient of 0.98 .

$\mathrm{R}_{0}=0,58 \cdot \mathrm{PO}_{2}+0.15$

The increasing oxygen pressure in the photocatalytic reactor from $0.2 \mathrm{MPa}$ to $0.6 \mathrm{MPa}$ the initial rate of phenol oxidation increases 1.9 times. These confirm the mechanism of preventing the electron-hole recombination due to the reduction of adsorbed oxygen on the surface $\mathrm{TiO}^{2}$ nanotube to form highly reactive oxygen species such as the superoxide ion and the hydroxyl radical. Due to its high reactivity and oxidizing power these reactive oxygen species instantly react with the dissolved phenol and to each other, whereby, we observe intensification photodegradation of phenol.

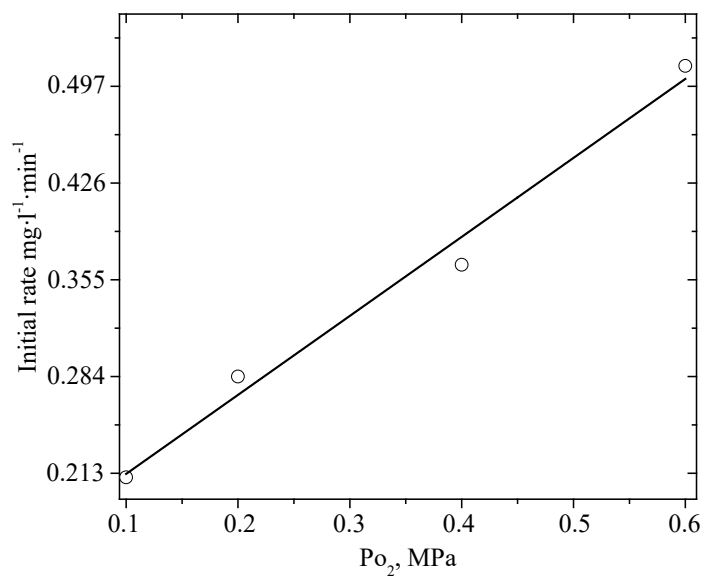

Figure 8. Dependence of initial rate of photocatalytic oxidation of phenol with presence of $\mathrm{TiO}_{2}$ nanotubes calcined at $600{ }^{\circ} \mathrm{C}$ under UV light irradiation on the oxygen pressure $\left([\mathrm{Ph}]_{0}-10 \mathrm{mg} \cdot \mathrm{l}^{-1},\left[\mathrm{TiO}_{2}\right]_{0}-0.1 \mathrm{~g} \cdot \mathrm{l}^{-1}\right)$.

\section{Conclusions}

The $\mathrm{TiO}_{2}$ nanotubes calcination temperature and the oxygen pressure were proven to have significant effect on the photodegradation of phenol. Notably, oxygen pressure and $\mathrm{TiO}_{2}$ nanotubes together showed a marked effect in photocatalytic oxidation of phenol. Increasing the oxygen pressure was beneficial for the photocatalytic degradation of phenol. Correspondingly, the photocatalytic oxidation rate and rate constants increased with an increase in oxygen pressure and $\mathrm{TiO}_{2}$ nanotubes calcination temperature up to $600{ }^{\circ} \mathrm{C}$. For the photocatalytic oxidation of phenol the dissolved oxygen at different pressure acted as electron acceptor to enhance the degradation efficiency. 


\section{References}

[1] S. Martha, D.P. Das, N. Biswal, and K.M. Parida, Facile synthesis of visible light responsive $\mathrm{V}_{2} \mathrm{O}_{5} / \mathrm{N}, \mathrm{S}-\mathrm{TiO}_{2}$ composite photocatalyst: enhanced hydrogen production and phenol degradation, J. Mater. Chem. 22 (2012) 10695-10703. https://doi.org/10.1039/c2jm30462g

[2] S. Ahmed, M.G. Rasul, W.N. Martens, R. Brown, and M. A. Hashib, Advances in heterogeneous photocatalytic degradation of phenols and dyes in wastewater: A review. Water. Air. Soil Pollut. 215 (2011) 3-29. https://doi.org/10.1007/s11270010-0456-3

[3] Y.-H. Shen, Removal of phenol from water by adsorption-flocculation using organobentonite. Water Res. 36 (2002) 1107-1114. https://doi.org/10.1016/S00431354(01)00324-4

[4] A.S. Fajardo, R.F. Rodrigues, R.C. Martins, L.M. Castro, and R.M. QuintaFerreira, Phenolic wastewaters treatment by electrocoagulation process using $\mathrm{Zn}$ anode. Chem. Eng. J. 275 (2015) 331-341. https://doi.org/10.1016/j.cej.2015.03.116

[5] A. Dabrowski, P. Podkościelny, Z. Hubicki, and M. Barczak, Adsorption of phenolic compounds by activated carbon-a critical review. Chemosphere. 58 (2005) 1049-1070. https://doi.org/10.1016/j.chemosphere.2004.09.067

[6] A. Mnif, D. Tabassi, M. Ben Sik Ali, and B. Hamrouni, Phenol removal from water by AG reverse osmosis membrane. Environ. Prog. Sustain. Energy. 34 (2015) 982-989.

[7] N.V. Pradeep, S. Anupama, K. Navya, H.N. Shalini, M. Idris, and U.S. Hampannavar, Biological removal of phenol from wastewaters: a mini review. Appl. Water Sci. 5 (2014) 105-112. https://doi.org/10.1007/s13201-014-0176-8

[8] M.A. Fox, and M.T. Dulay, Heterogeneous Photocatalysis. Chem. Rev. 93 (1993) 341-357. https://doi.org/10.1021/cr00017a016

[9] J. Herrmann, Heterogeneous photocatalysis: fundamentals and applications to the removal of various types of aqueous pollutants. Catal. Today. 53 (1999) 115-129. https://doi.org/10.1016/S0920-5861(99)00107-8

[10] U.I. Gaya, and A.H. Abdullah, Heterogeneous photocatalytic degradation of organic contaminants over titanium dioxide: A review of fundamentals, progress and problems. J. Photochem. Photobiol. C Photochem. Rev. 9 (2008) 1-12. https://doi.org/10.1016/j.jphotochemrev.2007.12.003 
[11] K. Pirkanniemi, and M. Sillanpää, Heterogeneous water phase catalysis as an environmental application: a review. Chemosphere. 48 (2002) 1047-1060. https://doi.org/10.1016/S0045-6535(02)00168-6

[12] U. Gaya, Heterogeneous photocatalysis using inorganic semiconductor solids (Springer Science \& Business Media, 2013).

[13] M. Pelaez, N.T. Nolan, S.C. Pillai, M.K. Seery, P. Falaras, A.G. Kontos, P.S.M. Dunlop, J.W.J. Hamilton, J.A. Byrne, K. O'shea, M.H. Entezari, and D.D. Dionysiou, A review on the visible light active titanium dioxide photocatalysts for environmental applications. Appl. Catal. B Environ. 125 (2012) 331-349. https://doi.org/10.1016/j.apcatb.2012.05.036

[14] M.R. Hoffmann, S.T. Martin, W. Choi, and D.W. Bahnemann, Environmental Applications of Semiconductor Photocatalysis. Chem. Rev. 95 (1995) 69-96. https://doi.org/10.1021/cr00033a004

[15] K. Nakata, and A. Fujishima, $\mathrm{TiO}_{2}$ photocatalysis: Design and applications. J. Photochem. Photobiol. C Photochem. Rev. 13 (2012) 169-189. https://doi.org/10.1016/j.jphotochemrev.2012.06.001

[16] A.L. Linsebigler, G. Lu, and J.T. Yates, Photocatalysis on $\mathrm{TiO}_{2}$ Surfaces: Principles, Mechanisms, and Selected Results, Chem. Rev. 95 (1995) 735-758. https://doi.org/10.1021/cr00035a013

[17] A. Fujishima, T.N. Rao, and D.A. Tryk, Titanium dioxide photocatalysis. J. Photochem. Photobiol. C Photochem. Rev. 1 (2000) 1-21. https://doi.org/10.1016/S1389-5567(00)00002-2

[18] J.-M. Herrmann, C. Duchamp, M. Karkmaz, B.T. Hoai, H. Lachheb, E. Puzenat, and C. Guillard, Environmental green chemistry as defined by photocatalysis. J. Hazard. Mater. 146 (2007) 624-629. https://doi.org/10.1016/j.jhazmat.2007.04.095

[19] A. Fujishima, X. Zhang, and D. Tryk, Heterogeneous photocatalysis: From water photolysis to applications in environmental cleanup. Int. J. Hydrogen Energy. 32 (2007) 2664-2672. https://doi.org/10.1016/j.ijhydene.2006.09.009

[20] D. Bahnemann, Photocatalytic water treatment: solar energy applications. Sol. Energy. 77 (2004) 445-459. https://doi.org/10.1016/j.solener.2004.03.031

[21] J. Qiu, S. Zhang, and H. Zhao, Recent applications of $\mathrm{TiO}_{2}$ nanomaterials in chemical sensing in aqueous media. Sensors Actuators, B Chem. 160 (2011) 875890. https://doi.org/10.1016/j.snb.2011.08.077 
[22] K. Rajeshwar, Photoelectrochemistry and the environment. J. Appl. Electrochem. 25 (1995) 1067-1082. https://doi.org/10.1007/BF00242533

[23] D.V. Bavykin, V.N. Parmon, A.A. Lapkin, and F.C. Walsh, The effect of hydrothermal conditions on the mesoporous structure of $\mathrm{TiO}_{2}$ nanotubes. J. Mat. Chem. 14 (2004) 3370-3377. https://doi.org/10.1039/b406378c

[24] R.J. Tayade, and D.L. Key, Synthesis and Characterization of Titanium Dioxide Nanotubes for Photocatalytic Degradation of Aqueous Nitrobenzene in the Presence of Sunlight. Materials Science Forum. 657 (2010) 62-74. https://doi.org/10.4028/www.scientific.net/MSF.657.62

[25] T.S. Natarajan, K. Natarajan, H.C. Bajaj, and R.J. Tayade, Energy Efficient UVLED Source and $\mathrm{TiO}_{2}$ Nanotube Array-Based Reactor for Photocatalytic Application. Ind. Eng. Chem. Res. 50 (2011) 7753-7762. https://doi.org/10.1021/ie200493k

[26] K. Shankar, J.I. Basham, N.K. Allam, O.K. Varghese, G.K. Mor, X. Feng, M. Paulose, J.A. Seabold, K.Sh. Choi, and C.A. Grimes, Recent Advances in the Use of $\mathrm{TiO}_{2}$ Nanotube and Nanowire Arrays for Oxidative photoelectrochemistry. J. Phys. Chem. C. 113 (2009) 6327-6359. https://doi.org/10.1021/jp809385x

[27] M.A. Rauf, and S.S. Ashraf, Fundamental principles and application of heterogeneous photocatalytic degradation of dyes in solution. Chem. Eng. J. 151 (2009) 10-18. https://doi.org/10.1016/j.cej.2009.02.026

[28] T. Velegraki, I. Poulios, M. Charalabaki, N. Kalogerakis, P. Samaras, and D. Mantzavinos, Photocatalytic and sonolytic oxidation of acid orange 7 in aqueous solution. Appl. Catal. B Environ. 62 (2006) 159-168. https://doi.org/10.1016/j.apcatb.2005.07.007

[29] A.M. Abdullah, N.J. Al-Thani, K. Tawbi, and H. Al-Kandari, Carbon/nitrogendoped $\mathrm{TiO}_{2}$ : New synthesis route, characterization and application for phenol degradation. Arab. J. Chem. 9 (2016) 229-237. https://doi.org/10.1016/j.arabjc.2015.04.027

[30] F.F. Orudzhev, F.G. Gasanova, Z.M. Aliev, and A.B. Isaev, Photoelectrocatalytic oxidation of phenol on platinum-modified $\mathrm{TiO}_{2}$ nanotubes. Nanotechnologies in Russia. 7 (2012) 482-485. https://doi.org/10.1134/S1995078012050102

[31] F.F. Orudzhev, F.G. Gasanova, Z.M. Aliev, A.B. Isaev, and N.S. Shabanov, Photoelectrocatalytic oxidation of phenol on $\mathrm{TiO}_{2}$ nanotubes under oxygen 
pressure. Russ. J. Electrochem. 51 (2015) 1108-1114.

https://doi.org/10.1134/S1023193515110130

[32] S.-H. Lin, C.-H. Chiou, C.-K. Chang, and R.-S. Juang, Photocatalytic degradation of phenol on different phases of $\mathrm{TiO}_{2}$ particles in aqueous suspensions under $\mathrm{UV}$ irradiation. J. Environ. Manage. 92 (2011) 3098-3104. https://doi.org/10.1016/j.jenvman.2011.07.024

[33] W.Y. Gan, M.W. Lee, R. Amal, H. Zhao, and K. Chiang, Photoelectrocatalytic activity of mesoporous $\mathrm{TiO}_{2}$ films prepared using the sol-gel method with tri-block copolymer as structure directing agent. J. Appl. Electrochem. 38 (2008) 703-712. https://doi.org/10.1007/s10800-008-9495-5

[34] K. Ángel-Sánchez, O. Vázquez-Cuchillo, M. Salazar-Villanueva, J.F. SánchezRamírez, A. Cruz-López, and A. Aguilar-Elguezabal, Preparation, characterization and photocatalytic properties of $\mathrm{TiO}_{2}$ nanostructured spheres synthesized by the Sol-Gel method modified with ethylene glycol. J. Sol-Gel Sci. Technol. 58 (2011) 360-365. https://doi.org/10.1007/s10971-011-2401-3

[35] C.A. Castro, A. Centeno, and S.A. Giraldo, Iron promotion of the $\mathrm{TiO}_{2}$ photosensitization process towards the photocatalytic oxidation of azo dyes under solar-simulated light irradiation. Mater. Chem. Phys. 129 (2011) 1176-1183. https://doi.org/10.1016/j.matchemphys.2011.05.082

[36] S.L. Orozco, C. A. Arancibia-Bulnes, and R. Suárez-Parra, Radiation absorption and degradation of an azo dye in a hybrid photocatalytic reactor. Chem. Eng. Sci. 64 (2009) 2173-2185. https://doi.org/10.1016/j.ces.2009.01.038

[37] D.-H. Tseng, L.-C. Juang, and H.-H. Huang, Effect of Oxygen and Hydrogen Peroxide on the Photocatalytic Degradation of Monochlorobenzene in Aqueous Suspension. Int. J. Photoenergy. (2012) 1-9. https://doi.org/10.1155/2012/328526 